NGTT Deel 54, Nommers 3 \& 4, September en Desember 2013

De Villiers, D Etienne ${ }^{1}$

University of Pretoria

\title{
An ethics of responsibility reading of Eduard Tödt's theory of the formation of moral judgement
}

\begin{abstract}
In the article the interpretation of Eduard Tödt's theory of the formation of moral judgements as descriptive of the six steps that are logically presupposed in the formation of all moral judgements is critically discussed. On the basis of an analysis of the four publications in which Tödt developed his theory it is demonstrated in the first part of the article that such an interpretation is incorrect. The normative nature of his theory is acknowledged. In the second part of the article a case is made for an ethics of responsibility reading of his theory. Each of the six steps in the process of the formation of moral judgements that Tödt distinguishes, is analysed. It is demonstrated that each of these steps entails a distinctive normative ethical approach that can be depicted as ethics of responsibility.
\end{abstract}

\section{INTRODUCTION}

It is a great honour for me to contribute to this Festschrift for Dirkie Smit in celebration of his sixtieth birthday. We have been close friends for almost three decades, undertook - together with our wives - a number of unforgettable tours and have had over many years, and especially during simultaneous sabbaticals in Germany and Princeton, intensive and - for me - inspiring theological exchanges. We have also jointly undertaken a number of memorable theological initiatives.

One of these theological initiatives was to co-author three Afrikaans articles on fundamental Christian ethical issues that were all published in Skrif en Kerk (Scripture and Church) between 1994 and 1996. In this contribution I wish to revisit one of these joint articles, namely (in translation) 'Why do we differ so on what the will of God Is? Comments on the formation of Christian moral judgements. The bulk of this article consists of an exposition of Eduard Tödt's ethical theory on the formation of moral judgements and an illustration of how the six steps he distinguishes play a role in that process. Because Tödt's publications on the topic were only available in German at that time, Dirkie's and my article helped to introduce Afrikaansspeaking theological students to his theory. ${ }^{2}$

I interpreted Tödt's theory at the time of co-writing the article with Dirkie as descriptive of the formation of all moral judgements. It was clear to me that Tödt does not assert that in the process moral agents always chronologically or psychologically follow the six steps he distinguishes. However, in my opinion, what he does assert is that these six steps are always logically presupposed in the formation of all moral judgements, even though those who make moral judgements are often not aware that it is the case. From the way postgraduate students

1 Etienne de Villiers is Professor Emeritus in the Department of Dogmatics and Christian Ethics, Faculty of Theology University of Pretoria.

2 Quite a number of theological students wrote their master's or doctoral theses on Christian ethics after

1996 using Tödt's six steps as an analytical tool in discussing particular Christian ethical issues. 
NGTT: Oopbron - http://ngtt.journals.ac.za

utilised Tödt's six steps as an analytical tool in their research I was not the only one who took such an interpretation as point of departure.

It was only recently, when I again read through four works Tödt wrote over a period of more than ten years and in which he explicitly and extensively dealt with the steps involved, that I began to wonder whether such an interpretation of the process was justified (Tödt 1977:81-93; 1979:31-71; 1988a:21-48; 1988b:49-84). First, it dawned on me that he indicates in his later writings that the six steps only play a role in the formation of a particular type of moral judgement. More importantly, it has become clear to me that Tödt is presenting an ideal typical analysis of a very specific approach to the formation of moral judgements that he himself favours, an approach that stands in contrast to some other approaches that have been developed in moral philosophy and Christian ethics and which, in his opinion, is more appropriate in our time than those approaches. He distinguishes his approach from the others as one based on an ethics of responsibility.

In the remainder of my contribution I attempt to substantiate the interpretation of Tödt's ethical theory of the formation ofmoral judgements as a responsibility ethics one. In order to do this I first argue why his theory cannot be interpreted as descriptive of the logical steps presupposed in all instances of the formation ofmoral judgements. In a second part I provide a responsibility ethics reading of Tödt's approach to the formation of moral judgements.

\section{TÖDT'S THEORY IS NORMATIVE IN NATURE}

It is not without reason that I (and others) initially interpreted Tödt's theory as purely descriptive of the logical steps presupposed in all formation of moral judgements. Especially the first version of his theory, entitled "Versuch zu einer Theorie ethischer Urteilsfindung" (1977) ("An attempt at formulating a theory on the formation of ethical judgements"), renders such an interpretation plausible. ${ }^{3}$ In this version Tödt asserts that he identifies in his scheme the essential elements (Sachmomente) that form part of the formation process of moral judgements and arranges them according to the objective logical order (sachlogische Reihenfolge) that applies to this process (Tödt 1977:84). The impression that he is claiming that the elements he identifies are presupposed in all formation of moral judgements is also strengthened by his use of the word "theory" (in the first version without the qualification "ethical"). He provided the following definition of "theory":

[A] system of precise concepts and assertions, which serves to order the factual knowledge in a certain area of study, and to explain and, eventually, also predict the order in which the data are related to one another (Tödt 1977:84) [my translation - EDV].

On account of this definition the conclusion that Tödt is providing a theoretically sound explication of the essential elements involved in the formation of moral judgements as such is certainly not far fetched.

\footnotetext{
3 In 1978 the greatest part of an issue of the Zeitschrift für Evangelische Ethik was devoted to the first version of Tödt's theory. In it Otfried Höffe (1978:181-187), Christian Link (1978:188-199) and Christopher Frey (1978:200-213) critically discussed the theory. Wolfgang Huber (1992:15 footnote 31) felt that the strong criticism of this version of the theory by Johannes Fischer (1989:91-118) was unfair. Fischer showed more appreciation in a later discussion of Tödt's theory - which took later versions of it into account (1994:226-234).
} 
NGTT Deel 54, Nommers 3 \& 4, September en Desember 2013

However, when one takes into account all the publications in which Tödt deals with the formation of moral judgements, the correctness of this interpretation becomes highly unlikely. First of all, he clearly indicates in the last two writings on this topic (published together in a book in 1988) that his scheme of six steps does not apply to all types of moral judgements. He denies, for example, in his "Versuch einer ethischen Theorie sittlicher Urteilsfindung" that it is not applicable to moral judgements in which we express a moral evaluation of the attitudes and actions of other people, or of the moral quality of institutions and relations. It rather applies to moral judgements that are elicited by serious concrete problems and culminates in decisions that lead to action (Tödt 1988a:21-22). He does not expand on why his scheme is not applicable to moral judgements of evaluation. It is, however, not difficult to see that the reason is that in such moral judgements some of the steps he identifies do not play a role. In the case of such moral judgements the point of departure is not a problem that engages an agent unconditionally and challenges him or her to take a decision that involves both mind and the will to act morally in order to solve or alleviate the problem.

In his "Die Zeitmodi in ihrer Bedeutung für die sittlicher Urteilsfindung" ("The significance of the different temporal modes for the formation of moral judgements"), Tödt narrows down the type of formation of moral judgements to which his scheme applies even further. He excludes the intuitive moral judgements that play an important role in everyday life from his analysis (Tödt 1988b:55). With that he acknowledges the valid insight of the moral philosopher Alasdair Maclntyre and the Christian ethicist Stanley Hauerwas that moral virtues, and not so much moral norms, play a pivotal role in providing moral guidance in everyday life. As moral judgements based on moral virtues are mostly not made in a process of conscious moral deliberation, but rather intuitively, there is no way that one can cogently argue that the steps Tödt distinguishes are logically presupposed.

Not only is it clear from the two essays mentioned that Tödt does not present his scheme of six steps as applicable to the formation of all types of moral judgements, but it is also clear that he does not see this scheme as a timeless one that is presupposed in the formation of at least a certain type of moral judgement. It is rather that he is convinced that in our time his proposed approach to the formation of moral judgements on moral problems that challenge moral agents is the most appropriate one. His reason for proposing this particular approach is that traditional approaches, like the casuistry approach, are not able to adequately deal with the complex new problems we face today as the result of rapid, modern, technological developments. These approaches were developed for a social environment that remained unchanged and stable for long periods of time and were, therefore, based on the conviction that all that is needed to reach a moral judgement is to apply the traditional ethos or a general moral principle to a particular issue. Given the complex problems we face today it is, in Tödt's opinion, advisable to in the formation of moral judgements rather depart from the stipulation of the problem that needs to be solved and to only then inquire into the criteria for right action (Tödt 1988b:50-51).

This, however, does not mean that Tödt supports a situation ethical approach to the formation of moral judgements. In fact, he strongly criticises situation ethics and clearly distinguishes his own approach from it (Tödt 1988b:58-59). Situation ethics - especially the version that was influential in Germany in the 1920s and that took as its point of departure Kierkegaard's understanding of "situation" - shares the conviction of ethical decisionism that we do not need norms that transcend a situation, but that the situation itself rather prescribes what should be done. The subjectivism and arbitrariness to which such situation ethics could lead became clear 
NGTT: Oopbron - http://ngtt.journals.ac.za

when influential proponents, such as the German jurist Carl Schmitt, actively supported and legitimated Hitler's rule (Tödt 1988b:58). Unlike these situation ethicists, Tödt does not believe that the situation can be isolated from the flow of history as if it is a sort of "eternity atom". In the process of moral judgement its relation to preceding historical developments should, therefore, be taken into account by way of a thorough situation analysis (Tödt 1988b:59).

That Tödt does not develop a theory on the timeless elements that are presupposed in the formation of moral judgements becomes even clearer when his exposition of the different steps in his two later works is taken into account. As more attention will be given to his understanding of what is involved in each of these steps in the next paragraph, I restrict myself here to a brief discussion of only the fifth step, namely the testing of the morally communicative and obligatory character of the selected course of action (Tödt 1988a:39-41; 1988b:74-77). This step is not included in the first version of Tödt's theory. In the first version he rather introduced as sixth step what he calls "retrospective adequacy control" (Tödt 1977:83). Criticism that "adequacy control" could hardly be seen as a separate step that follows the decision on right action, but should rather be regarded as inherent to each of the first five steps apparently convinced Tödt to omit this step (for criticism cf. Höffe 1978:186). In his later version he instead introduced the above-mentioned step as the fifth one. With this step he proposed that a decision on right action should not be taken before the moral agent had determined whether there might be something regarding the possible options for action that does not relate to other people, are unacceptable to them or may cause division. It inevitably involves real consultation with stakeholders. What is rather obvious is that, unlike the other steps, this step cannot in any way be interpreted as one that is logically presupposed in the formation of moral judgements. It is clearly prescriptive or normative in nature and only makes sense in a theory that is itself a normative proposal on the most appropriate approach to forming moral judgements in our day.

This discussion of the status of Tödt's theory - whether it is descriptive or normative in nature - raises the more general question of whether any theory on the formation of moral judgements could ever be purely descriptive in nature. In preparation of this contribution I also read the works of philosopher Otfried Höffe (1977) and theologians Hermann Ringeling (1984) and Dietz Lange (1992) who, in critical dialogue with Tödt, develop their own views on the elements involved in the formation of moral judgements. First of all, it is obvious that their versions of the steps involved in the process differ significantly from Tödt's and from one another. It is clearly not universally evident what these steps are! Even more significant is that the differences between these versions can at least in some instances be traced back to different normative elements that the mentioned authors find necessary to introduce into the schemes they develop: Höffe's conviction that no adequate formation of moral judgements is possible without a creative, constructive design of suitable solutions to the problems at hand (Höffe 1977:186); Ringeling's insistence on the fact that recognition should be given to the deontological Kantian question ("What do we want to do?"), as well as to the teleological question ("What should we do?") and the responsibility ethics question ("What can we do?") (Ringeling 1984:419-420); and Dietz's assertion that relevant, concrete norms based on the criterion of being human (such as the protection of life and the possibility of taking responsibility) should also be taken into account (Dietz 1992:521). One may wonder whether any theory on the formation of moral judgements can be purely descriptive. Such theories mostly, if not always, seem to be based on normative assumptions and to be normative or prescriptive in nature. 
Tödt's ethical theory of the formation of moral judgements rests on two important presuppositions that have to be taken into account in its interpretation. The first is that his construction of such a theory was motivated by his desire to find an appropriate contemporary approach in Protestant (German: evangelische) ethics. The second is that, in Tödt's opinion, a theory of the appropriate formation of moral judgements in our time has to be based on responsibility ethics. In the tradition of the Reformation the salvation the loving God grants believers is central. Protestants, especially in the Lutheran tradition, interpreted this salvation to include freedom from the specific norms of the law. In his disputation with Hieronymous Weller, Martin Luther even declared that we are empowered by faith to make new laws, new decalogues that are better than those of Moses (WA 39 l, 47). This unfortunately led to the widespread misunderstanding among Protestants that all norms have lost their obligatory significance (Tödt 1979:54,56). The fear of making specific norms binding on Christians also led to a lack of concretisation in Protestant ethics and uncertainty among members of Protestant churches on how they should relate their faith to urgent moral issues of our time and on what specific steps they should take to decide on morally acceptable actions. In Tödt's view, this is an unfortunate situation that should be rectified. Protestant Christians should take the task given in the Bible of discerning the will of God seriously in order to learn what is good, acceptable and perfect (Rom. 12:2). They should accept that they are empowered by faith to reflect on serious moral issues, to make judgements on morally right actions and to act accordingly (Tödt 1988a:46-47). It is partly to overcome the lack of concretisation of Protestant ethics and to provide guidance to contemporary Christians towards making moral judgements that Tödt develops his theory. In his own words:

In a theological framework a theory of the formation of moral judgements serves to give clarity on how God's salvific claim on our lives accompanies and moves us even in the most concrete aspects of our relationships with fellow human beings, the environment and ourselves (Tödt 1988a:47) [my translation - EDV].

In the development of his theory, Tödt often refers to those who contributed to the development of an ethics of responsibility: Max Weber, Georg Picht, Hans Jonas and also Dietrich Bonhoeffer. He is clearly convinced that the insights gained from an ethics of responsibility should be incorporated in a contemporary theory of the formation of moral judgements and sets out to do just that in the construction of his own theory (cf. Tödt 1979:53-56; 1988a:43-46; 1988b:51, 79-81). Tödt shares the conviction of the responsibility ethicists that the traditional approach to ethics has been overtaken by rapid and incisive changes in contemporary social reality. In the traditional approach the emphasis was on retrospective evaluation (Tödt 1979:36). The central concept was the concept of "duty". The presupposition was that it is possible to identify a number of typical moral issues in personal and social life and to formulate a number of corresponding duties that adequately deal with these moral issues. As Max Weber has already pointed out in his famous speech "The profession and vocation of politics" (1919), the "ethics of conviction", which he contrasts to "ethics of responsibility", entails only a narrow responsibility to strictly obey a prescribed duty without taking any consequences into account (Weber 1994:309-369). However, in our present social reality - especially as a result of the rapid development of modern technology - we are ever more confronted with new and complex moral issues, which cannot be dealt with by means of available duties. These issues confront us with new tasks and challenges that entail comprehensive responsibilities and reveal the need to find moral agents who 
NGTT: Oopbron - http://ngtt.journals.ac.za

are willing and able to take on these responsibilities. What complicates the matter further is that modern technology often has unintended, long-term, negative consequences that pose serious risks for future generations. An ethics of responsibility recognises these drastic changes in the moral landscape as well as the need to make "responsibility" the key concept of ethics instead of "duty".

Tödt does not only acknowledge in general terms that insights gained from an ethics of responsibility serve as presuppositions of his own theory. He also incorporates these insights into his exposition of the six steps in the formation of moral judgements. In the remainder of this contribution I, therefore, turn my attention to a brief demonstration of the responsibility ethics dimension of each of the steps.

\section{The perception, acceptance and stipulation of the problem as a moral problem}

Tödt is aware of the fact that the ethics of responsibility differs from other ethical approaches, among others, by its emphasis on taking the pressing problems of the modern period morally serious. As he strives to construct a theory of the formation of moral judgements in tandem with the ethics of responsibility, Tödt is convinced that the "point of departure for the formation of moral judgements in the vein of an ethics of responsibility must be to tackle the problems that crop up from the context of life and history" (Tödt 1988b:51). Taking such problems morally serious entails, in his opinion, to first perceive them from a moral perspective and to take them on as moral problems that engage one personally and unconditionally. He is quite aware that this means deliberately going against the tendency in our time to see these problems as purely sectorial problems - for example, economic or technological - that can and should be solved by purely functional or technical means. Second, to take these problems seriously means stipulating precisely the exact nature of the moral problem that has to be solved. Tödt recognises that people involved often differ on what the precise nature of the moral problem is. They can also differ on which moral problem is more serious and should be attended to first. By emphasising that they ought to critically investigate their own prejudices based on interests, try to express themselves in an understandable way and strive to reach agreement on the moral problem that has to be tackled he, in my opinion, adopts and recommends a responsibility ethics approach. Such an approach entails the responsibility to do everything reasonable that is needed to solve the serious moral problem at hand. To reach consensus on the moral problem is an indispensable step in the process of resolving such moral problems (Tödt 1988a:30-31; 1988b:56-58).

\section{Analysis of the situation}

Taking seriously the pressing problems that face us in our communal and personal lives today, implies that the concrete situation in which these problems are embedded should also be taken seriously by thoroughly analysing it. That a thorough situation analysis is an imperative of responsibility ethics has been emphasised by most of its proponents (cf. for example, Weber 1994:309-369). Tödt recognises this imperative by underlining the need to analyse the situation (the "real context", according to him) within which such problems present themselves and explicitly states that "[t]o not analyse a situation as thoroughly as possible is negligence" (Tödt 1988a:32). Part of this situation analysis is to take the historical context of the problem into account. Situation analysis has as task "to get clarity on possible and commendable future actions and only succeeds in understanding the situation concretely if it reveals which past events have given shape to the present constellation of the problem" (Tödt 1988b:62). 
NGTT Deel 54, Nommers $3 \& 4$, September en Desember 2013

What has to be taken into account is that even actions that follow from good intentions (or from the "good will", to use Kantian terminology) sometimes have very bad consequences (Tödt 1988a:31-32). This is something that Max Weber already convincingly pointed out in his criticism of the ethics of conviction and his defence of the ethics of responsibility in "The profession and vocation of politics" (Weber 1994:309-69). Therefore, it is imperative - especially from the perspective of responsibility ethics - that the possible and foreseeable future effects and side effects of present and past actions, but also of alternative actions that are considered as moral solutions to present problems, should also be determined as accurately as possible (Tödt 1988a:32).

\section{Design and evaluation of options for action}

Max Weber already pointed out in "The profession and vocation of politics" that proponents of an ethics of conviction need not consider different options for action, because a very specific action is already prescribed by the duty they accept as their own. It is, however, different in the case of proponents of the ethics of responsibility. The latter have to consider different courses of action by deciding on a specific goal to strive toward and by looking at different means available to achieve that goal (Weber 1994:309-369). This includes weighing up the consequences of the different courses of action. In the same vein, Tödt emphasises the need to design and evaluate different options for action in order to find the best solution to a moral problem. He adds: "The person who designs options for action in a responsible way cannot ignore effects and side effects, because all moral actions play out in the field of inter-human relationships" (Tödt 1988b:64). An attempt should be made at predicting and managing the future by way of prognosis and planning. By analysing trends in the present the consequences of different courses of action should be determined as accurately as possible. Tödt agrees with Weber that the consideration of morally suspect or ambivalent means in order to ensure the achievement of a morally good goal is sometimes unavoidable. There are, however, moral limits to the means that may be utilised. The moral agent should never act contrary to his or her own conscience as his or her own moral identity will then be at stake (Tödt 1988a:34-35).

\section{Testing norms, goods and perspectives}

It is one of the fundamental insights of the ethics of responsibility that in the modern era moral norms, virtues and values have lost their monopoly in all spheres of life. As the differentiation of social spheres like politics and the economy progressed, it became increasingly clear that the validity of functional norms, virtues and values, and not only of moral norms, virtues and values, has to be recognised. Weber was one of the first to incisively reflect on the growing competition moral considerations experience from functional ones. In formulating the ethics of responsibility he attempted to find a solution that would do justice to both political and moral principles (Weber 1994:309-369). Tödt is also clearly aware of the fact that moral norms are not the only applicable norms in the process of the formation of moral judgements. Available social norms, often embedded in institutions and social roles, are not necessarily moral in nature, but often nonmoral and sometimes even immoral, as they express discriminatory societal practices. There are also "goods" or material values that societies recognise as desirable. In the process of the formation of moral judgements all these social norms and "goods" must be scrutinised for their applicability, but also tested for their moral quality. Tödt is adamant that we should not give in to the modern tendency to allow only functional considerations to play a role in deciding what 
NGTT: Oopbron - http://ngtt.journals.ac.za

actions are to be taken or policies implemented. In deciding on applicable moral norms, (what Tödt calls) "perspectives" can and should play a decisive role. These are the broader belief systems in which particular beliefs about life, the world and God are integrated. These perspectives - according to Tödt - can and should also serve as sources when the need arises to formulate completely new moral norms to make decisions regarding the new and complex problems we are faced with today (Tödt 1988a:37-39; 1988b:65-74). With that we touch on what I like to call the "meta-responsibility" implied by the ethics of responsibility to formulate applicable new moral norms where none is available in order to salvage the moral dimension of life in our time.

\section{Testing the morally communicative and obligatory character of the selected course of action}

Tödt finds it necessary to introduce this step because he agrees with Georg Picht that an understanding of the concept "norm" as referring to a fixed principle that has validity for all people of all times would contradict an ethical approach that takes "responsibility" as its central notion. The reason for saying this is that each person is confronted by history with his or her own specific responsibility regarding the moral problems that have to be solved. On the other hand, an overly individualistic interpretation of the norm concept has to be avoided, in any case when it comes to moral norms. Implicit in all moral judgements based on moral norms is the standard of the unity of humanity that has to be respected. For that reason processes of interaction and communication have to be implemented in order to find common norms and "goods" and to ensure that all stakeholders acknowledge their validity (Tödt 1988a:39-41; 1988b:74-77).

\section{The judgement decision}

That responsibility ethics obliges a person to take a deliberate decision in the face of contemporary moral problems is something that Weber already underlined (Weber 1994:30969). Encroaching modernisation processes of rationalisation and bureaucratisation have resulted in diminished room for acting in accordance with one's own ethical convictions. A responsibility ethics approach, according to Weber, nonetheless insists that a politician should not shy away from making decisions needed for the realisation of those ideals that unconditionally appeal to him or her and to take on the responsibility to find the means to do so - even if it inevitably involves morally ambivalent means. In a similar vein, Tödt emphasises that a person may not automatically act according to a moral judgement made according to the first five steps of the process. The possibility remains that one becomes paralysed by uncertainty or fear. No action will follow unless a deliberate decision is taken that involves not only cognitive insights gained in preceding steps, but also the will to do what is required and to take responsibility for the consequences of one's actions (Tödt 1988a:41-42; 1988b:77-78).

\section{Conclusion}

In light of the discussion above it follows that the interpretation of Tödt's theory as descriptive of the logically presupposed steps in the formation of moral judgements is inaccurate. It should rather be understood as a normative theory of the most appropriate approach to the formation of moral judgements in our time. As this approach is based on insights gained by the ethics of responsibility it can be described as "a responsibility ethics approach to the formation of moral judgements". 


\section{BiBLIOGRAPHY}

De Villiers, D. E. and Smit, D. J. 1996. Waarom verskil ons so oor wat die wil van God is? Opmerkings oor Christelike morele oordeelsvorming (Why do we differ so on what the will of God Is? Comments on the formation of Christian moral judgements), Skrif en Kerk 17(1), 31-47.

Fischer, J. 1989. Glaube als Erkenntnis. Zum Wahrnehmungscharakter des christlichen Glaubens. München: Chr. Kaiser.

Fischer, J. 1994. Leben aus dem Geist. Zur Grundlegung christlicher Ethik. Zürich: Theologischer Verlag.

Frey, C. 1978. Humane Erfahrung und selbskritische Vernunf. Marginalien zum "Versuch zu einer Theorie ethischer Urteilsfindung" von Heinz Eduard Tödt. Zeitschrift für Evangelische Ethik (22), 200-213.

Höffe, O. 1978. Bemerkungen zu einer Theorie ethischer Urteilsfindung. Zeitschrift für Evangelische Ethik (22), 181-187.

Huber, W. 1992. Strukturen verantwortlichen Lebens. Die Bedeutung Heinz Eduard Tödt für die theologische Ethik. Unpublished paper read at the Academic Memorial Day in Heidelberg, Germany, on 6 May 1992.

Lange, D. 1992. Ethik in evangelischer Perspektive. Grundlagen christlicher Lebenspraxis. Göttingen: Vandenhoeck and Ruprecht.

Link, C. 1978. Überlegungen zum Problem der Normen in der theologischen Ethik. Zeitschrift für Evangelische Ethik (22), 188-199.

Ringeling, H. 1984. Ethische Normativität und Urteilsfindung. Zeitschrift für Evangelische Ethik (28), 402424.

Tödt, H. E. 1977. Versuch zu einer Theorie ethischer Urteilsfindung. Zeitschrift für Evangelische Ethik (21), 81-93.

Tödt, H. E. 1979. Kriterien evangelisch-ethischer Urteilsfindung. Grundsätzliche Überlegungen angesichts der Stellungnahmen der Kirchen zu einem Kernkraftwerk in Wyhl am Oberhein. In Tödt, H. E., Der Spielraum des Menschen. Theologische Orientierung in den Umstellungskrisen der modernen Welt. Gütersloh: Gerd Mohn, 31-71.

Tödt, H. E. 1988a. Versuch einer ethischen Theorie sittlicher Urteilsfindung. In Tödt, H. E. Perspektiven theologischer Ethik. Munich: Chr. Kaiser, 21-48.

Tödt, H. E. 1988b. Die Zeitmodi in ihrer Bedeutung für die sittliche Urteilsfindung. In Tödt, H. E.

Perspektiven theologischer Ethik. Munich: Chr. Kaiser, 49-84.

Weber, M. 1994 (1919). The profession and vocation of politics. In Lassmann, P. and Speirs, R. (eds.), Weber. Political writings. Cambridge: Cambridge University Press, 309-369.

\section{KEY WORDS}

Eduard Tödt

Ethics of responsibility

Formation of moral judgements

Max Weber

Norm

\section{TREFWOORDE}

\section{Eduard Tödt}

Etiek van verantwoordelikheid

Vorming van morele oordele

Max Weber

Norm

Contact Details/Kontakbesonderhede

D. Etienne de Villiers

Emeritus professor: Christian ethics, Faculty of Theology, University of Pretoria

South Africa

etienne.joan@vodamail.co.za 